\title{
REGIONAL DISPARITIES IN USE OF FUNDS FROM OPERATIONAL PROGRAM ENVIRONMIENT IN THE CZECH REPUBLIC
}

\section{REGIONÁLNÍ DISPARITY LERPÁNÍ PROSTř EDKŠ Z OPERA LNÍHO PROGRAMU G̦IVOTNÍ PROSTř EDÍ V LESKÉ REPUBLICE}

\section{ING. VERONIKA ǴRANKOVÁ}

\author{
Katedra regionální ekonomie a správy $\mid$ Depart. of Regional Economics and Administration \\ Ekonomicko-správní fakulta Faculty of Economics and Administration \\ Masarykova univerzita Masaryk University \\ $\triangle$ Lipová 41 a, 60200 Brno, Czech Republic \\ E-mail: 253657@mail.muni.cz
}

\begin{abstract}
Annotation
An unsatisfactory environmental situation is one of the reasons of unsteady regional development and emergence of regional disparities in the Czech Republic. The article is aimed at the regional disparities in the use of the financial resources from the Operational Program Environment in the Czech Republic in the programing period 2007 i 2013. The analysis is based on the dependence between the data from Ministry of Environment of the Czech Republic that are published during the implementation of the Operational Program Environment and the regional statistical data from the Czech Statistical Office focused on environmental issues. Results show that the allocation of the financial resources from the Structural Funds is distributed quite unevenly along the individual regions NUTS 3 in the Czech Republic. Moreover, some regions NUTS 3 show funding disproportional with the state of their environment. Consequently, differentiation between regions might deepen in the future.
\end{abstract}

Key words

regional disparities, Operational program Environment, structural funds, environment, NUTS 3

\section{Anotace}

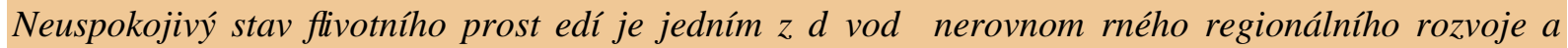

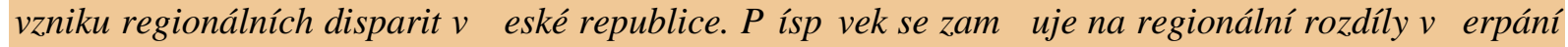
finan!̣ich prost ŚedkT z Operal ního Programu G̦votní Prost Śdí v L eské republice v programovém obdobi 2007 ï 2013. Analýza je zaloǵena na závislosti mezi daty Ministerstva G̦votního ProstŚedí, které jsou publikovány bhem realizace Operaḷního Programu G̦ivotní ProstSedí a údaji z regionálních statistik Ĺ eského statistického úSadu, zamnśených na environmentální problematiku. Výsledky ukazují, ǵe pŚdinování finan! ních prostŚdkT ze Strukturálních FondT je rozloǵeno zcela

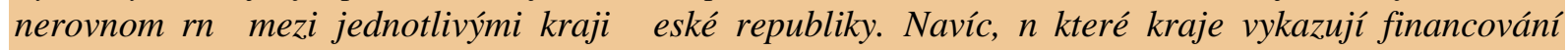
nevyváǵené se stavem jejich ğvotního prostŚdí. Tudíg by se mohly nerovnosti mezi regiony v budoucnu prohlubovat.

Klịıvá slova

regionální disparity, Operaḷ ní program G̦ivotní prostŚedí, strukturální fondy, ğvotní prostŚedi, kraje

JEL classification: $Q 53, R 58$ 


\section{Introduction}

The European Cohesion Policy is based on a financial solidarity between the regions of the European Union Member States. Through the European policy of economic and social cohesion, the European Union is trying to achieve steady economic and social development of these regions. This policy is mainly focused on the poorer regions which receive the most of the support. Within help of the Structural Funds, the resources are allocated with the intention to reduce social and economic disparities between regions.

Any disparity is generally understood as an inequality, diversity or difference in certain phenomenon. Regional (spatial) disparities reflect differences in expression level of intensity of the investigated economic phenomenon observed in the regions of the country (OECD, 2002). In the regional context, the Ministry of regional development $\mathrm{CZ}$ defines regional disparities as unjustified regional differences in the level of economic, social and environmental development. This definition also reflects the areas (economic, social and environmental) in which regional disparities may arise. According the segmentation of the horizontal perspective of regional disparities, the area of environmental issues belong to spatial disparities which are associated with positional relationships in the wider context of geographic, natural, transport and technical conditions. Disparities in environment are fundamental in reflecting the actual state of environment and they are measurable by objective and subjective indicators. (Alois Kutscherauer et all, 2010)

In the terms of disparities, the objectives of the regional policy in the Czech Republic are focused on reducing unfavorable regional differences and supporting development of specifically problematic territories. (G̣itek, Klímová, 2008) One of the main reasons of the uneven development of regions and emergence of regional disparities in the Czech Republic is a persistently unsatisfactory environmental situation (especially in regions: Moravia-Silesia and the North-West, large cities ï Prague, Brno, Plzen, Usti nad Labem, Pardubice-Hradec Kralove). (MRD, 2007) It is reasonable that the regional policy also tries to find a solution to the insufficient quality of the environment. The Operational Program Environment (OPE) represents the possibility to finance environmentally based projects and thereby to improve the quality of the environment in the Czech Republic.

\section{Objectives and methods}

The article is focused on the regional disparities in use of financial resources from OPE in the Czech Republic in programing period 2007 ï 2013. The analysis is aimed at monitoring the regional disparities between regions NUTS 3 in financing from OPE and the chosen indicators of the quality of environment. Due to differences in economic development and the subsistent interregional discrepancies at the regional level is likely that the possibility of co-financing from OPE could show a regional diversity. The regional policy is based on principle of concentration, which means that greater part of the financial resources from the Structural Funds are concentrated on the poorest regions with the most difficulties.(ec.europe.eu) Considering this fact, the financial resources from OPE should be allocated to the regions with the greatest problems, in terms of the individual components of the environment and according to the state of environment in these regions.

The aim of the article is to evaluate regional disparities in the use of financial support from the OPE, which funds activities to improve quality of environment in the Czech Republic. The purpose of the OPE should be to reduce the regional disparities, in terms of the quality of environment. The intention is to find out if the financial support from Structural Funds in frame of OPE is concentrated in regions with the greatest problems in terms of the state of environment, or if the location of the approved projects is random and the allocation is affected by other factors. The analysis is based on dependence of the regional statistical data from the Czech Statistical Office (CZSO) on the data from the Ministry of Environment of the Czech Republic (MoE), which is responsible for the program implementation. Initial data for the analysis are the amount of subsidy of approved projects allocated to the regions NUTS 3 in the Czech Republic (beside Priority axis 8 Technical assistance). For comparison with 
subsidy one economic indicator (regional GDP per capita) and several environmental indicators were selected (investment in environment, number of industry companies, share of cleaned waste water from water discharge into sewer, share of population supplied with water from conduit, population overexposure to high concentration of $\mathrm{PM}_{10}$ - particulate matter 10 micrometer $\ddot{i}$ highest 24 hour concentration, waste production of industry companies, area of protected natural areas). The aim of the analysis is to determine if there is any connection between the state of the environment in the individual regions and utilization of the financial subsidies from OPE and if it is possible to find a relationship with the economic development of regions. The analysis provides information if the financial resources of the OPE are concentrated in the most affected areas in terms of the environment.

\section{The Operational Program Environment}

The Operational Program Environment (OPE) is one of the thematic operational programs included in the Convergence objective and in terms of the financial resources it is the second biggest Czech operational program. OP Environment contains 8 priority axes dividing the operational program into logical units, which are further elaborated through areas of intervention, or even sub-areas of intervention to define what types of projects may be supported under the respective priority axis.

The OP Environment is focused on improving the quality of the environment and thereby the health of the population. It contributes to improving the quality of the air, water and soil; deals with waste management and industrial pollution; supports landscape cultivation and use of renewable energy sources as well as the construction of the infrastructure for environmental education and awareness. (MoE, 2013)

The total allocation of the financial resources for OP Environment from the European Funds is 4.92 $\boldsymbol{b n}$. EUR, which amounts to approximately $18.4 \%$ of all resources assigned for the Czech Republic from the EU funds. $85.7 \%$ of the allocation of financial resources is funded from the European Regional Development Fund (ERDF - 702482212 EUR) and 14.3\% of financial resources from Cohesion Fund (CF - 4215384886 EUR). The Managing Authority for the OP Environment is the Ministry of the Environment of the Czech Republic (MoE) which is responsible for the program implementation and the intermediate body is State Environmental Fund (SEF). (MoE, 2013)

Figure 1 depicts the share of the individual priority axes of the Operational Program Environment, the data are based on programing document (MoE, 2013).

Fig. 1: Share of the Individual Priority Axes of the Operational Program Environment

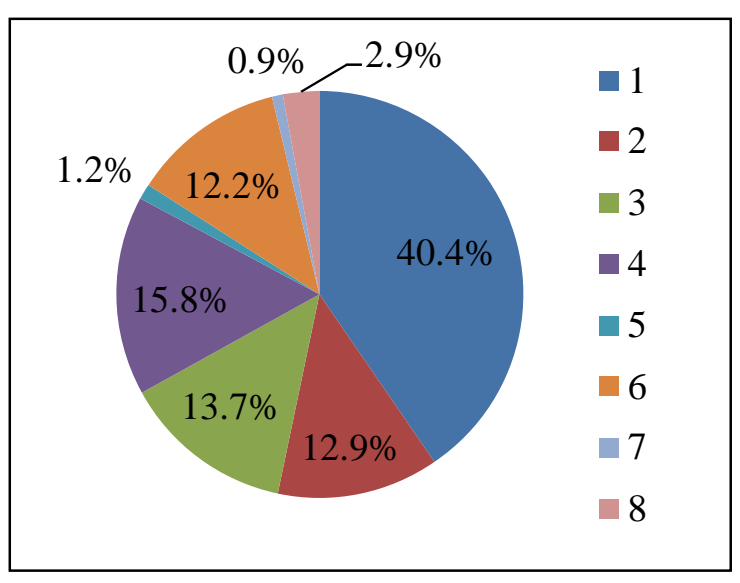

1. Improvement of water management infrastructure and reduction of floods risk

2. Improvement of air quality and reduction of emissions

3. Sustainable use of energy sources

4. Improvement of waste management and rehabilitation of old ecological burdens

5. Limitation of industrial pollution and environmental risks

6. Improvement of state of nature and landscape

7. Development of infrastructure for environmental education, consultancy and awareness raising

8. Technical assistance

Source: Ministry of Environment 2013, own design

In the OPE a total number of 17481 projects with the request for support of almost $11 \mathrm{bn}$. EUR was received from the beginning of the period until the end of 2012. By the end of the year 2012 the projects in the amount of $5.3 \mathrm{bn}$. EUR were recommended for funding, from which the projects 
amounting to $4.3 \mathrm{bn}$. EUR were rejected or withdrawn by the applicants and the projects in the amount of EUR 1.2 billion were in the process of assessment and evaluation. In the end of 2012 the projects in the amount of $91 \%$ of the allocation of the whole programming period were recommended for funding. The situation is worse with the projects with the decision of grant of subsidy. In the end of 2012 the decision of grant of subsidy was issued for $59 \%$ of the recommended projects to $40 \%$ of allocation ( $2.3 \mathrm{bn}$. EUR). For this reason, there is a risk that by the end of 2013 part of the liability could be automatically cancelled. (MoE, SEF, 2013). Table 1 shows the financial allocation of the OPE. Currently the approved projects comprise almost the whole allocation from the Structural Funds, but the amount of paid out funds implicate only $27 \%$ of a total allocation of approved projects.

Tab. 1: Financial allocation of the Operational Program Environment 2007 - 2013

\begin{tabular}{|l|c|c|c|c|c|}
\hline $\begin{array}{l}\text { Priority } \\
\text { axis }\end{array}$ & Fund & $\begin{array}{c}\text { Community } \\
\text { contribution }(\mathrm{CZK})\end{array}$ & $\begin{array}{c}\text { Approved projects } \\
(\mathrm{CZK})\end{array}$ & $\begin{array}{c}\text { Approved } \\
\text { projects }(\%)\end{array}$ & $\begin{array}{c}\text { Approved projects paid } \\
\text { out funds (CZK) }\end{array}$ \\
\hline 1 & $\mathrm{CF}$ & 54565880627,44 & 53477008274,15 & $98,00 \%$ & 25122984061,65 \\
\hline 2 & $\mathrm{CF}$ & 17400966788,80 & 16785712879,66 & $96,46 \%$ & 3010621875,75 \\
\hline 3 & $\mathrm{CF}$ & 18466332115,28 & 17768675774,52 & $96,22 \%$ & 12881881209,73 \\
\hline 4 & $\mathrm{CF}$ & 21307306282,64 & 17849330672,91 & $83,77 \%$ & 9672470398,69 \\
\hline 5 & ERDF & 1663020654,96 & 1375070046,90 & $82,69 \%$ & 595545705,99 \\
\hline 6 & ERDF & 16448189758,00 & 14041396424,83 & $85,37 \%$ & 6716367004,39 \\
\hline 7 & ERDF & 1164901484,32 & 1058140991,20 & $90,84 \%$ & 594114027,80 \\
\hline 8 & $\mathrm{CF}$ & 3929675457,68 & N/A & N/A & N/A \\
\hline In total & CF+ERDF & 134946273169,12 & 122355335064,17 & $90,67 \%$ & 33471000222,35 \\
\hline $\begin{array}{l}\text { In total } \\
\text { CF }\end{array}$ & CF & 115670161271,84 & 105880727601,24 & $91,54 \%$ & 50687957545,82 \\
\hline $\begin{array}{l}\text { In total } \\
\text { ERDF }\end{array}$ & ERDF & 19276111897,28 & 16474607462,93 & $85,47 \%$ & 7906026738,18 \\
\hline
\end{tabular}

Financial amounts are converted at the exchange rate of 31.3.2014 - 27.44 CZK/EUR

Source: Ministry of Environment: Operational Program Environment ï Program document 2013, List of approved projects 2014, own design and calculations

\section{Disparities in use of financial subsidies from OPE}

Differences in the economic development and subsistent regional discrepancies in the regions NUTS 3 could influence the use of Structural Funds from OPE and therefore regional disparities may occur. It should be noted that the location of the implementation of the projects may not always correspond with the municipality of the project, whereas large segment of the beneficiaries are municipalities usually carrying out activities of projects on their territory.

From the graphically expressed differentiation of the regions NUTS 3 (fig. 2), in terms of total subsidy of approved projects, it is evident that South-Moravian, then Central Bohemia and Moravian-Silesian regions received the highest amount of financial resources from OPE. In case of South-Moravian (10.4 bn. CZK) and Central Bohemia (9.5 bn. CZK) region, the amount of structural help is affected by the Priority axis 1 , which is focused on improvement of condition of both surface and underground water, the quality and supply of the population's drinking water and reduction the risk of floods. This priority axis has the biggest community contribution ( $40.4 \%$ of whole allocation) and represents the relevant share of allocation ( $43.7 \%$ of all subsidies of all approved projects) in the most of the regions.

The Priority axis 2, which is aimed at improvement of air quality and reduction of emissions, represent the most important share on total subsidy in Moravian-Silesian region (6.7 bn. CZK). Because the condition of air pollution is very critical in Moravian-Silesian region, extensive subsidy for improvement of the air quality responds to the needs of this region. 
The least of structural help is concentrated to Karlovy Vary region (2.6 bn. CZK) and Prague (3.2 bn. CZK), although some regions in Karlovy Vary region are considered as regions with concentrated state support and Prague with the highest concentration of industry belongs to the polluted areas in the Czech Republic. Whole territory of Usti nad Labem region (7.1 bn. CZK) belongs to regions with concentrated state support and areas with polluted environment, but its amount of subsidy is only half of total subsidy in Moravian-Silesian region.

The major segment in most of the regions represents also the Priority axis 4 (focused on waste management rehabilitation of existing ecological burdens), Priority axis 3 (aimed at renewable energy sources) where the relative share of total subsidies is considerable in all regions. Slightly significant share comprise the Priority axis 6 (focused on prevention of reduction of the biodiversity and increase of the ecological stability of the landscape).

\section{Fig. 2: Map of total subsidy allocated to regions NUTS 3 in OPE 2007- 2013}

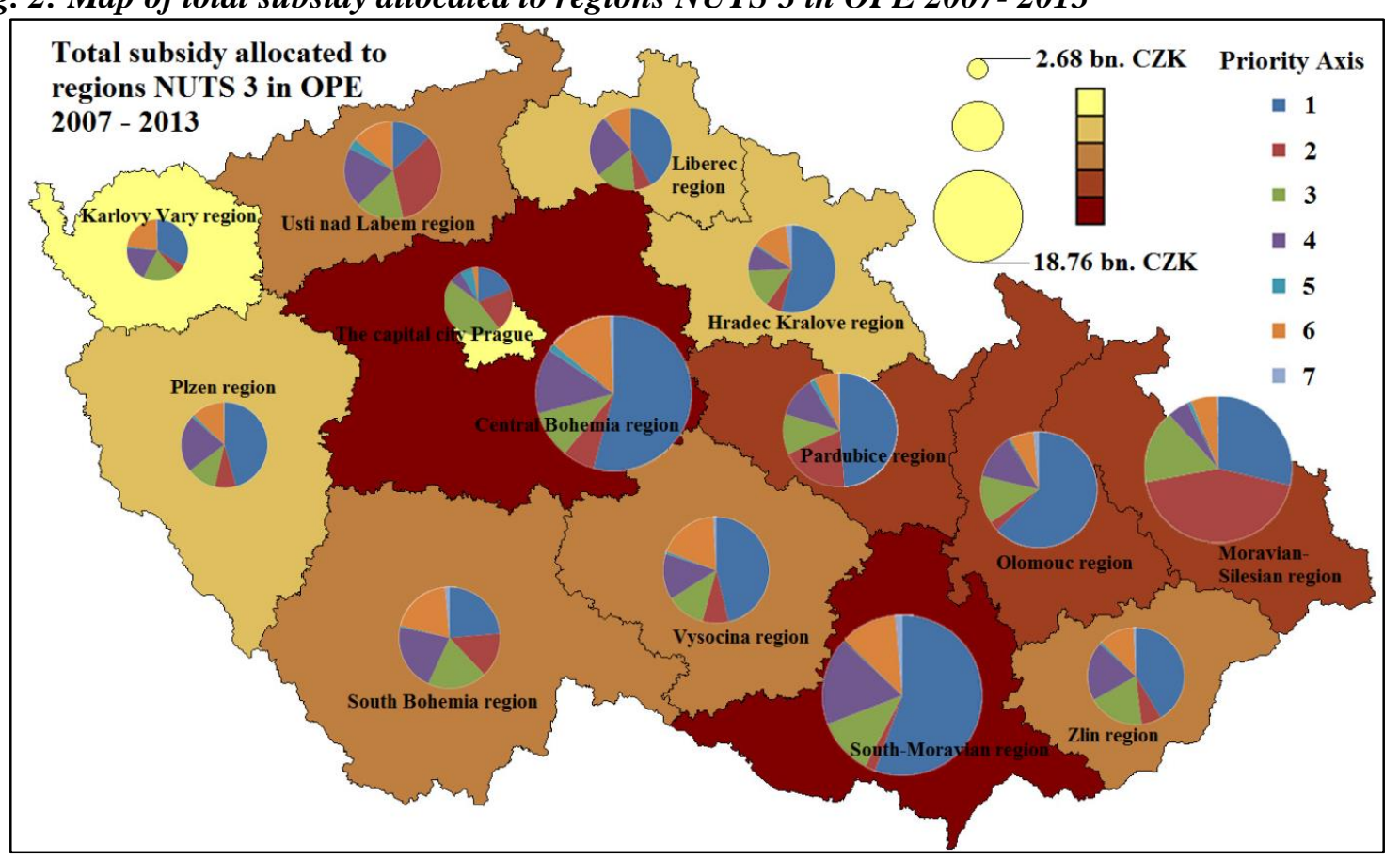

Source: Own design and calculation based on data from MoE, 2014

Figure 3 shows variation (standard deviation) in the relative representation of the regions on the total subsidy in frame of the priority axis. The lowest variability among the regions is shown by Priority axis 3, which means the relative equability in use of the funds across the Czech Republic. Priority axis 4 distribution is also relatively even between regions NUTS 3. The highest variability is in Priority axis 2 , which is caused by almost $40 \%$ share on subsidy in Moravian-Silesian region.

Fig. 3: Variability of regions NUTS 3 in priority axis OPE 2007 - 2013

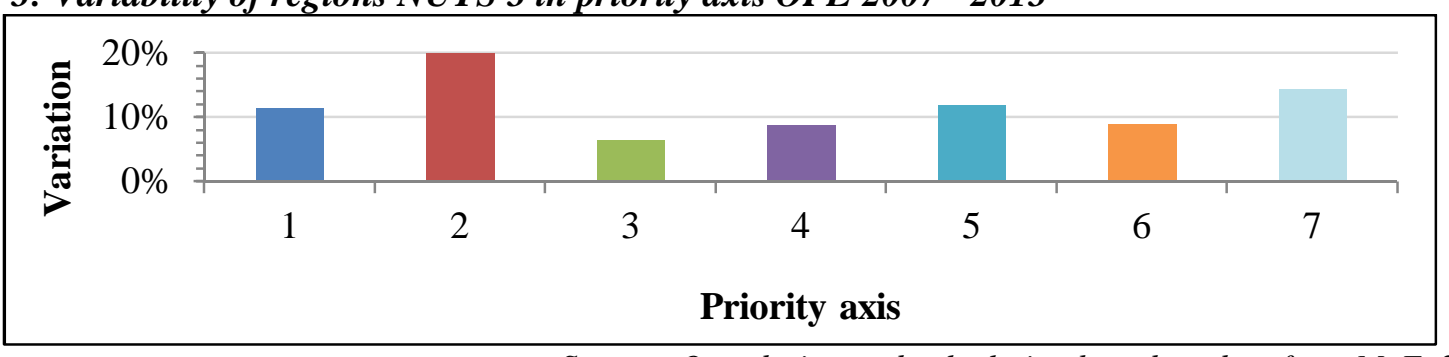

Source: Own design and calculation based on data from MoE, 2014

The following figure (fig. 4) shows relationships between economic and environmental indicators and the subsidy of approved projects supported under the respective priority axis of OPE. Due to the 
availability of relevant statistical data from CZSO, it is possible monitor only selected indicators on the regional level NUTS 3.

Fig. 4: Relationships between selected indicators and use of Structural Funds in OPE in NUTS 3

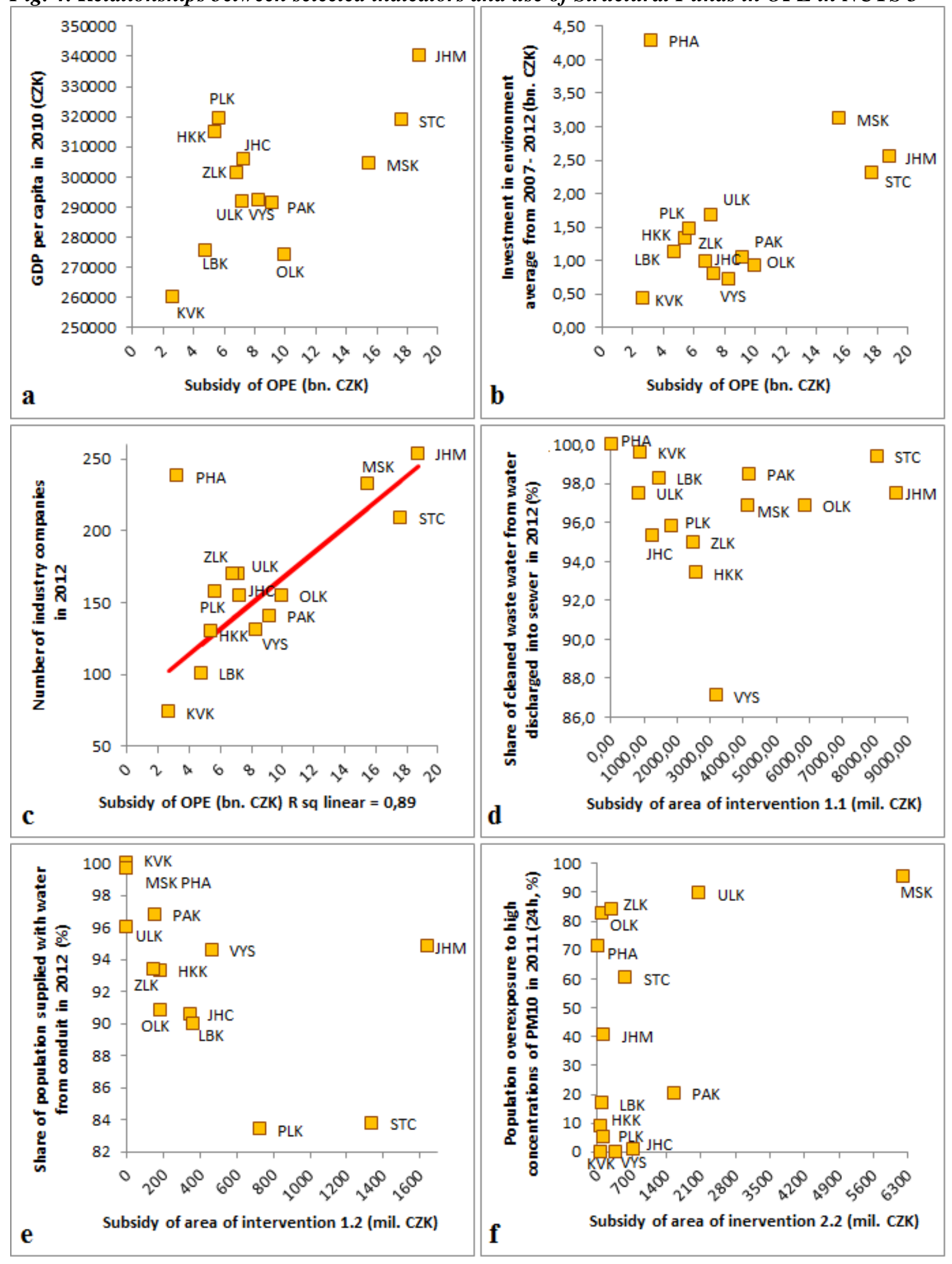




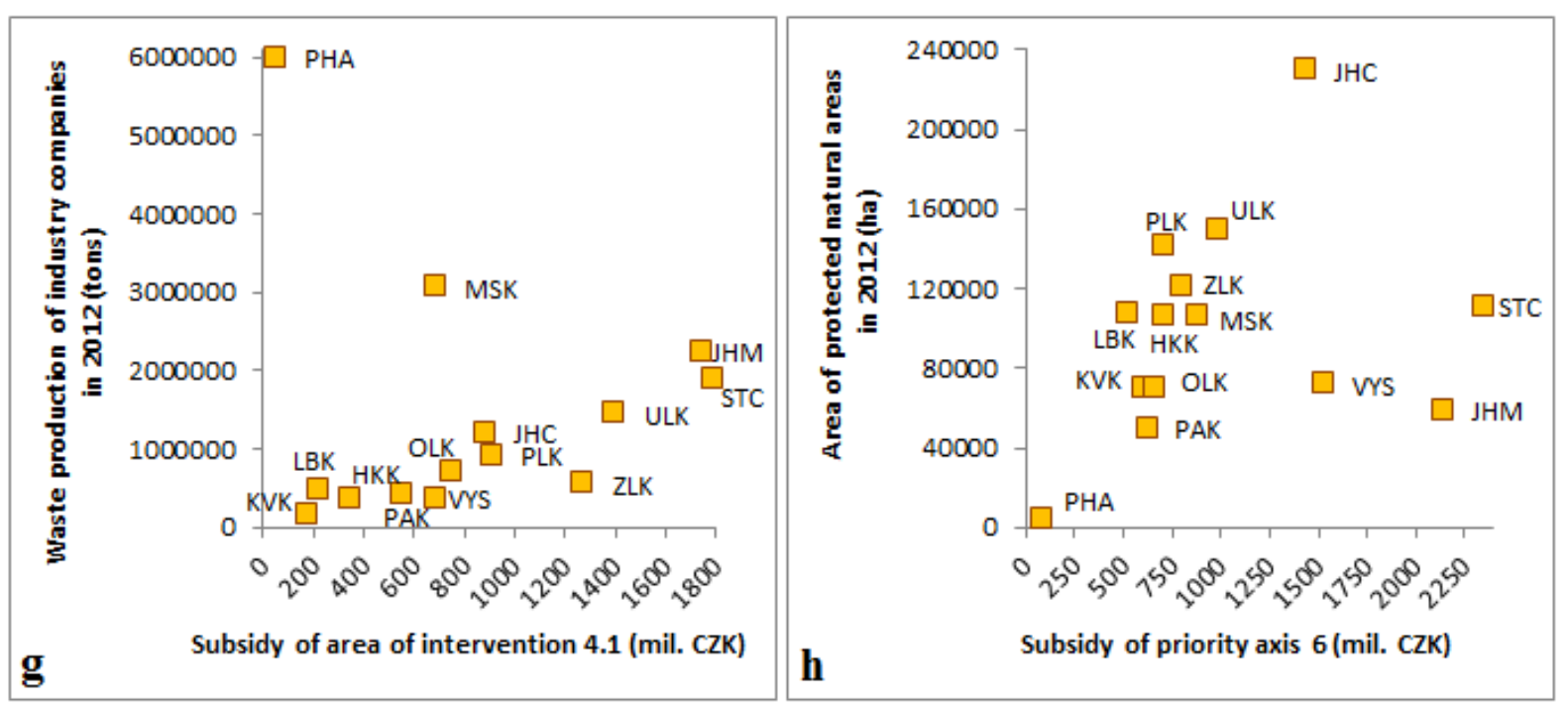

PHA - The capital city Prague, JHC - South Bohemia region, JHM - South-Moravian region, KVK - Karlovy Vary region, HKK - Hradec Kralove region, LBK - Liberec region, MSK - Moravian-Silesian region, OLK Olomouc region, PAK - Pardubice region, PLK - Plzen region, STC - Central Bohemia region, ULK - Usti nad Labem region, VYS - Vysocina region, ZLK - Zlin region

Source: Own design and calculation based on data from MoE, 2014 and CSZO 2007 - 2012

The first monitored dependence is the relationship between the regional GDP per capita (Prague with GDP per capita 771773 CZK is omitted for better comparison) and the amount of subsidy of approved project. From the figure (a) it is obvious that the financial support is concentrated in the regions with higher regional GDP. Although there is no strong dependence between these two indicators, it is questionable whether these regions (especially South-Moravian and Central Bohemia regions) really need the financial assistance to a considerable extent.

The figure (b) determines the relationship between the investment in the environment (national resources) and the resources from the Structural Funds. If it could be assumed that the national funds reflect the real needs of the individual regions NUTS 3 in the field of environment, then the funding from the OPE is allocated randomly without significant regularity. It is evident that MoravianSilesian, Central Bohemia and South-Moravian regions are more successful in request for financial resources from OPE than other regions, despite the fact they are receiving almost $35 \%$ of national resources invested in environment during period 2007 ï 2012.

The only monitored indicator which shows strong dependence on the total approved subsidies is the number of industrial companies (figure c). Since the result of concentrated industrial production leads to environmental pollution, the financial resources from the Structural Funds are more allocated to the regions with intensive industrial production.

Figure (d) shows how the subsidy in the Area of intervention 1.1 focused on reduction of water pollution is related to share of the cleaned waste water from water discharged into sewer. Although almost all regions embody that more than $90 \%$ water is cleaned, the subsidy of area of intervention 1.1 is allocated randomly among the regions NUTS 3. In comparison with other regions NUTS 3 Vysocina with only $87 \%$ cleaned water does not get as much financial resources as it is needed.

Figure (e) determines relation between share of population supplied with water from conduit and the financial resources from the Structural Funds to the Area of intervention 1.2 aimed at drinking water quality improvement. From the figure it is obvious that the amount of funds rises with declining supply of water. Only South-Moravian region shows the highest subsidy, even if it does not belong to regions with compelling problems of water supply.

The next figure (f) represents the relationship between population overexposure to high concentration of $\mathrm{PM}_{10}$ and structural help from the Area of intervention 2.2 focused on reduction of emissions. Although the resources are allocated quite randomly, most of the funds are concentrated to MoravianSilesian region with extremely critical state of air pollution.

The figure (g) shows that allocation to Area of intervention 4.1 aimed at waste management rises with increasing waste production of industry companies among the regions NUTS 3. Exceptions are 
Moravian-Silesian region and Prague, waste production of which is much higher than the rest of the regions and the allocated subsidy does not respond to the tendency of the other regions.

The last figure (h) determines the funding of the Priority axis 6 and the protected nature areas in the regions. Subsidy of the Priority axis 6 generally reflects the area of protected areas in each region. Despite of this, South-Moravian and Central Bohemia region apply for more resources than other regions, in frame of protected areas. The Priority axis 6 has relatively diversified range of supported activities but the presence of protected areas plays a relatively important role.

\section{Conclusion}

The allocation of the financial resources from the Structural Funds on the projects focused on improvement of the quality of the environment is distributed quite unevenly along the regions NUTS 3 in the Czech Republic. These regions embody considerable regional disparities in use of funds from the Operational Program Environment, although the purpose of the OPE should be to reduce regional disparities in terms of quality of the environment. Regarding to the principle of concentration, the funds from OPE should be allocated to the regions with the significant environmental problems, but the initial analysis suggests that the funding does not always follow this principle. In addition, some regions NUTS 3 are more successful in use of the financial assistance from the Structural Funds in comparison with the state of the environment in these regions. Therefore, the differentiation between the regions might deepen in the future.

\section{References}

[1] Czech Statistical Office., (2014). Public database. [online]. [cit. 2014-04-04]. Available at: $<$ http://vdb.czso.cz/vdbvo/en/uvod.jsp>

[2] European Comission., (2014). Regional Policy. [online]. [cit. 2014-04-04]. Available at: <http://ec.europa.eu/regional_policy/how/principles/index_en.cfm>

[3] GaREP. Methodic support of regional development in the Czech Republic, (2014). [online]. [cit. 2014-0404]. Available at: <http://www.regionalnirozvoj.cz/index.php/diskuze.437/items/definice-pojmudisparita.html>

[4] KUTSCHERAUER, A., AT ALL., (2010). Regional Disparities. Disparities in the Regional Development, their Concept, Identification and Assessment. Ostrava: EkF VG்-TU. ISBN: 978-80-248-2335-5.

[5] Ministry of Environment of the Czech Republic, State Environmental Fund., (2013). OPE: Annual report for year 2012 [online]. [cit. 2014-04-04]. Retrieved from WWW: <http://www.opzp.cz/soubor-kestazeni/49/14862-vyrocni_zprava_opzp_2012_vc_priloh.pdf>

[6] Ministry of Environment of the Czech Republic., (2013). Operational Program Environment ï Program document [online]. [cit. 2014-04-04]. Available at: <http://www.opzp.cz/soubor-ke-stazeni/51/15458pd_opzp_brezen_2014.pdf>

[7] Ministry of Environment of the Czech Republic., (2014). OPE: List of beneficiaries to date 31. 1. 2014 [online]. [cit. 2014-04-04]. Available at: 〈http://www.opzp.cz/sekce/504/prehledy-schvalenych-projektu/>

[8] Ministry of Regional Development of the Czech Republic., (2007). National strategic reference framework of the Czech Republic 2007 ï 2013. [online]. [cit. 2014-04-04]. Retrieved from WWW: <http://www.strukturalni-fondy.cz/getmedia/dffd7e3a-7026-4b63-b6d9-b0eac30b581d/Narodnistrategicky-referencni-ramec-EN-cervenec $>$

[9] OECD. Geographic Concentration and Territorial Disparity in OECD Countries., (2002). Paris: OECD Publications Service, 2002.

[10] Ǵ̦TEK, V., KLÍMOVÁ V. Regionální politika. Brno: Masarykova univerzita, 2008. ISBN 978-80-2104761-7.

This paper was created as a part of the specific research project no. MUNI/A/0768/2013 ñ The theoretical-methodological basis of regional assessment of development projects and their verification on the selected examplesñat Masaryk University. 